\title{
Wykorzystanie zasobów kosmicznych Unii Europejskiej dla realizacji celów Wspólnej Polityki Bezpieczeństwa i Obrony ${ }^{1}$
}

Unia Europejska jako aktor globalny, nie tylko rozszerza podmiotowo swoje działania zewnętrzne, ale także nieustannie wzbogaca swoje instrumentarium. Istotnym instrumentem stają się w tym kontekście zasoby kosmiczne, które pozwalają Unii na realizację celów polityki zagranicznej i bezpieczeństwa oraz promowanie swoich wartości w sposób pełniejszy i znacznie bardziej autonomiczny, co potwierdzają stosowne zapisy Traktatu z Lizbony. Zasada spójności działań zewnętrznych, podkreślona w katalogu nadrzędnych zasad UE, między innymi w art. 21 ust. 3 z innymi politykami Unii sprawia, że realizacja polityki kosmicznej Unii Europejskiej związana jest również działaniami podejmowanymi na arenie międzynarodowej. Należy do nich także i przede wszystkim realizacja zadań i celów Wspólnej Polityki Bezpieczeństwa i Obrony, gdzie wykorzystanie zasobów i zdolności technologicznych Unii Europejskiej ma kluczowe znaczenie dla skuteczności działań w tym wymiarze. Należy jednak podkreślić, że Europejska Polityka Kosmiczna pozostaje nadal w początkowej fazie rozwoju, a zatem jej oddziaływanie na Wspólną Politykę Bezpieczeństwa i Obrony należy ocenić raczej przez pryzmat możliwości wykorzystania zasobów kosmicznych. Z drugiej strony należy również wskazać, że zasoby kosmiczne są wykorzystywane przez Unię Europejską od momentu utworzenia Centrum Satelitarnego w Torrejon, którego zdaniem jest przetwarzanie danych uzyskanych ze zdjęć satelitarnych na potrzeby Wspólnej Polityki Bezpieczeństwa i Obrony.

Celem artykułu jest wskazanie możliwości i przykładów faktycznego wykorzystania zasobów kosmicznych na potrzeby Wspólnej Polityki Bezpieczeństwa i Obrony, ze szczególnym uwzględnieniem unormowań prawnych analizowanego zjawiska. Struktura artykułu przedstawia się następująco. W części pierwszej wskazane zostaną podstawowe dokumenty, stanowiące ramy dla wykorzystania przestrzeni kosmicznej na potrzeby Wspólnej Polityki Bezpieczeństwa i Obrony. Część druga pracy zawierać będzie charakterystykę realizowanych programów, jak również zakres i analizę zbieżności Wspólnej Polityki Bezpieczeństwa i Obrony z działaniami podejmowanymi przez Unię Europejską w innych obszarach swej aktywności. Część trzecia, będąca jednocześnie podsumowaniem, poświęcona zostanie proponowanym zmianom pro-

1 Artykuł jest efektem realizacji grantu własnego NCN pt. Europejska polityka kosmiczna nr N N116 321638, którego kierownikiem i wykonawcą jest autorka artykułu. 
wadzącym do zacieśnienia współpracy UE z Europejską Agencją Kosmiczną i wpływu możliwych efektów proponowanych działań na Wspólną Politykę Bezpieczeństwa i Obrony.

\section{Podstawy do wykorzystania zasobów kosmicznych dla realizacji celów Wspólnej Polityki Bezpieczeństwa i Obrony}

Grupa podmiotów zaangażowanych w kształtowanie europejskiej polityki kosmicznej i planowanie wykorzystania zasobów kosmicznych dla potrzeb Wspólnej Polityki Bezpieczeństwa i Obrony jest dość liczna. Do podmiotów tych zaliczyć należy Komisję Europejską, Parlament Europejski, Radę Europejską, Europejską Agencję Kosmiczną, prezydencje, państwa członkowskie UE, a w szczególności te, które jako priorytet prezydencji ustanowiły politykę kosmiczną oraz podmioty pozapaństwowe zaangażowane $\mathrm{w}$ przemysł kosmiczny. W skład wymienionych instytucji wchodzą przedstawiciele w zasadzie tych samych państw członkowskich UE i można by przyjać, że europejska polityka kosmiczna jest wypadkową interesów państw członkowskich, realizowaną na poziomie Unii Europejskiej. Byłoby to jednak nadmierne uproszczenie, bowiem cele jakie przyświecają poszczególnym państwom nie są zawsze zbieżne, a ich możliwość oddziaływania na proces decyzyjny i kształt polityki kosmicznej również charakteryzuje się własną dynamiką.

Przesłanek wykorzystania możliwości, jakie przedstawiają zasoby kosmiczne w kontekście globalnej obecności Unii Europejskiej należy szukać w latach sześćdziesiątych XX wieku. Wraz z wyniesieniem na orbitę pierwszego sztucznego satelity stało się jasne, że postęp technologiczny, który stał się symbolem potęgi państw i możliwości oddziaływania na środowisko międzynarodowe, będzie miał również implikacje militarne. Na przykład przyjęta w 1965 roku, rezolucja zgromadzenia Unii Zachodnioeuropejskiej zalecała Radzie UZE podjęcie kroków, które miałyby prowadzić do ustalenia długo- i krótkofalowych celów europejskiej aktywności w kosmosie. W innym przypadku nie będzie możliwe dotrzymanie kroku Rosji i Ameryce (WEU, 1965, Annex I). Tym samym zanim państwa europejskie uzyskały możliwości wykorzystania kosmosu trwała dyskusja nad potencjalnym wykorzystaniem zasobów kosmicznych. Należy jednak podkreślić, że dyskusja ta zapoczątkowana została w określonym kontekście geopolitycznym, a powstanie Europejskiej Agencji Kosmicznej, której podstawowym zadaniem jest realizacja wyłącznie celów pokojowych sprawiło, że dyskusje nad możliwościami, jakie niesie za sobą przestrzeń kosmiczna dla działań o charakterze militarnym z konieczności toczyły się poza strukturami Wspólnot Europejskich. Przykładem może być przyjęta w 1984 roku rekomendacja Zgromadzenia Parlamentarnego UZE dotycząca militarnego wykorzystania przestrzeni kosmicznej, gdzie stwierdzono, iż „wierząc, że zdolności w przestrzeni kosmicznej będą kluczowym determinantem działań wojennych w przyszłości i że w z wojskowego punktu widzenia różnice potencjału pomiędzy narodami mającymi zdolności kosmiczne i innymi będzie tak samo duża jak dziś różnica pomiędzy państwami nuklearnymi i tymi, które nie posiadają broni jądrowej - Europa musi po prostu uwzględnić ten fakt [...], a UZE jest wartościowym forum debaty i analizy skutków dla obrony Europy Zachodniej przy użyciu 
najnowszych militarnych technologii kosmicznych, jak również strukturą instytucjonalną nieskrępowaną politycznymi ograniczeniami konwencji ESA dla rozpoczęcia przez czołowe państwa kosmiczne Europy Zachodniej obronnego europejskiego wojskowego programu kosmicznego" (Western European Union, 1984).

Lata po zakończeniu zimnej wojny przyniosły kolejne raporty i rezolucje związane z militarnym wymiarem aktywności państw europejskich w przestrzeni kosmicznej. Warto podkreślić przyjętą 1998 roku Deklarację Rzymską, w której Rada Ministerialna Unii Zachodnioeuropejskiej wskazała na powstanie dokumentu zatytułowanego $W E U$ Space Policy, zainicjowanego przez grecką prezydencję (Western European Union, 1998, s. 10). W dokumencie tym wskazano na konieczność opracowania polityki kosmicznej Unii Zachodnioeuropejskiej, a jak podkreślano w kolejnych latach nie jest to zadanie łatwe, gdyż wszelka aktywność kosmiczna posiada także wymiar militarny i bezpośrednio dotyka to żywotnych interesów państw. W jednej z kolejnych rekomendacji Zgromadzenia Unii Zachodnioeuropejskiej zauważono między innymi „organizacja efektywnej współpracy w obszarze tak wrażliwym jak wywiad wojskowy nie jest łatwym zadaniem" (Western European Union, 2008, s. 300), a zatem polityka kosmiczna dająca nieograniczone możliwości gromadzenia danych również dotknięta będzie tym problemem.

Wymiar militarny aktywności kosmicznej pojawia się w dokumentach Unii Zachodnioeuropejskiej także już po utworzeniu Europejskiej Polityki Bezpieczeństwa i Obrony (Słomczyńska, 2007a; Słomczyńska, 2007b). W roku 2001 na posiedzeniu Zgromadzenia Unii Zachodnioeuropejskiej przyjęty został raport $A$ joint European space strategy: security and defence aspects, w którym wskazano, że do wypełnienia założeń Europejskiego Celu Operacyjnego niezbędne jest wykorzystanie zasobów przestrzeni kosmicznej. Satelity, zdaniem twórców raportu, umożliwią nie tylko określenie warunków pogodowych do przeprowadzenia operacji militarnej, ale również pomogą w dokładnym określeniu celów, pozwolą monitorować przemieszczanie się jednostek cywilnych i wojskowych, umożliwią ocenę podjętych działań, jak również dostarczą danych wywiadowczych o potencjalnych wrogach, obejmujących nie tylko zdjęcia, ale również wywiad elektroniczny (Western European Union, 2001, s. 8).

W kolejnym dokumencie przyjętym przez Zgromadzenie Unii Zachodnioeuropejskiej w 2004 roku zatytułowanym „The space dimension of the ESDP” podkreślono, że niedawne kryzysy międzynarodowe pokazały jak ważna jest rola systemów kosmicznych we właściwej ocenie sytuacji i efektywnym wykorzystaniu sił zaangażowanych w rozwiązanie konfliktu. Zasoby kosmiczne to także gwarancja autonomiczności Wspólnej Polityki Bezpieczeństwa i Obrony i aby to osiagnąć w dłuższej perspektywie konieczne jest posiadanie przez Unię Europejską całościowych rozwiązań obejmujących stacje naziemne, centra przetwarzania danych satelitarnych, systemy telekomunikacyjne, satelity nawigacyjne oraz systemy rozpoznania pogodowego (Western European Union, 2004). We wskazanym raporcie pojawiła się także rekomendacja, by w Europejskiej Agencji Obrony utworzony został wydział zajmujący się technologiami kosmicznymi, tak by była możliwa koordynacja działań podejmowanych w ramach ESDP, które zawierają komponent kosmiczny. Ponadto zasugerowano, by w Centrum Satelitarnym Unii Europejskiej Torrejon (EUSC) wyodrębnić specjalną komórkę wojskową (Western European Union, 2004, s. 5). Specjalny wydział EUSC wspierający działania 
ESDP powstał jednak dopiero w 2008 roku, co pozwoliło na dostarczanie danych w czasie krótszym niż 44 godziny od uzyskania zdjęć satelitarnych (Asbeck, 2008, s. 22).

Wraz z pracami na forum Zgromadzenia Parlamentarnego UZE pojawiały się raporty Parlamentu Europejskiego oraz komunikaty Komisji Europejskiej podkreślające konieczność uwzględnienia zasobów kosmicznych w rozwoju Europejskiej Polityki Bezpieczeństwa i Obrony. W raporcie Parlamentu Europejskiego wskazano wprost, że chociaż UE traktuje instrumenty „soft power” takie jak dyplomacja, współpraca, czy działania polityczne na równi z instrumentami militarnymi i w obu tych grupach instrumentów należy uwzględnić politykę kosmiczną (Parlament Europejski, 2006, s. 9). Podkreślono także, że w kontekście interesów i celów bezpieczeństwa Unii Europejskiej należy zdefiniować jakie działania w przestrzeni kosmicznej należy uznać za akceptowalne. Jednocześnie zaakcentowano fakt, iż podział na militarne i cywilne zastosowania zasobów kosmicznych jest nieprawdziwy i przynosi efekty przeciwne do zamierzonych, a Unia Europejska powinna wyraźnie podkreślać, że celem jej nie jest wykorzystanie zasobów kosmicznych w zamiarach agresywnych (Parlament Europejski, 2006, s. 9).

Co istotne, polityka kosmiczna UE skupia się na pokojowym wykorzystaniu i badaniu przestrzeni kosmicznej, a nie jej zbrojeniu, które jest postrzegane jako główne zagrożenie dla Unii, poszczególnych państw członkowskich czy wręcz każdego obywatela UE. Można zatem mówić o sekurytyzacji przestrzeni kosmicznej, która staje się kluczowa z punktu widzenia bezpieczeństwa, a nawet przetrwania. Tym samym Unia Europejska skupia swoją uwagę w większym stopniu na bezpieczeństwie kosmicznym, a nie na obronie kosmicznej czy wykorzystaniu zasobów kosmicznych do powiększania swojej potęgi. To podejście wynika z całościowej kultury strategicznej Unii Europejskiej. Można więc stwierdzić, że UE potrzebuje polityki kosmicznej, żeby umożliwić Europie skorzystanie z bardziej efektywnej koordynacji technologii i zasobów w celu wzmocnienia bezpieczeństwa europejskiego i międzynarodowego jednocześnie zapobiegając rozwojowi elementów destabilizujących, takich jak testowanie, rozmieszczenie i użycie broni przeciwsatelitarnej czy broni w przestrzeni kosmicznej lub z przestrzeni kosmicznej.

W raporcie Parlamentu Europejskiego zauważono także, iż polityki kosmiczne państw europejskich są zorientowane zarówno na cele militarne, jak i cywilne, podczas gdy Europejska Agencja Kosmiczna dąży wyłącznie do celów pokojowych i odrzuca tym samym możliwość wykorzystania swoich zasobów do celów militarnych. Z kolei Unii Europejska posiada kompetencje w obszarze bezpieczeństwa i obrony, a zatem wolna jest od ograniczeń, jakie istnieją w ESA. Wymaga to jednak jasnego i otwartego podejścia do kwestii wykorzystania zasobów kosmicznych dla Europejskiej Polityki Bezpieczeństwa i Obrony. Wymaga to zatem stałego i przewidywalnego finansowania programów kosmicznych przez UE, ale także decyzji o charakterze politycznym, które przeciwdziałać będą militaryzacji przestrzeni kosmicznej.

Ujęcie przedstawione w raporcie Parlamentu Europejskiego zbliżone jest do doktryny „zdolności przetrwania”, proponowanej przez część autorów (Gleason, 2006). Podkreślana jest bowiem i uwypuklana kwestia wykorzystania przestrzeni kosmicznej na potrzeby efektywnej realizacji celów WPBiO. Akcentuje się zatem, że jeśli powstanie system europejskiej obrony, to niezbędne jest posiadanie narzędzia implementacji 
WPBiO, które obejmować powinny autonomiczne zdolności obserwacji ziemi z przestrzeni kosmicznej i nawigację satelitarną (Brachet, Deloffre, 2006, s. 95). Ponieważ, jak wskazane zostało w innej części tej pracy, brak jest obecnie autonomicznych zasobów kosmicznych Unii Europejskiej można postawić tezę, że obecnie jesteśmy w fazie przejściowej, podczas której są tworzone podstawy organizacji i zarządzania, na potrzeby Europy, która staje się mocarstwem kosmicznym. Moment osiagnięcia statusu mocarstwa kosmicznego zależy jednak nie tylko od uzyskania zasobów przez UE, ale również od tego jakie zasoby uzyskają inne państwa. Dlatego też szczególnie ważnym jest, by wraz z dążeniem do zapewnienia autonomii w wykorzystaniu zasobów kosmicznych we Wspólnej Polityce Bezpieczeństwa i Obrony podejmować także działania, które zagwarantowałoby iż przestrzeń kosmiczna nie stanie się areną wyścigu zbrojeń (Mutschler, Venet, 2012). Nie bez znaczenia jest fakt, że decydenci europejscy uwzględniają także działania podejmowane przez inne państwa, takie jak Rosja czy Chiny, zmierzające do militaryzacji przestrzeni kosmicznej (Maogoto, Freeland, 2008).

Kolejne dokumenty istotne dla rozwoju europejskiej polityki kosmicznej w kontekście Europejskiej Polityki Bezpieczeństwa i Obrony to opublikowane w roku 2003 komunikaty Komisji European Space Policy. Green Paper (Komisja Europejska, 2003b) oraz White Paper on Space (Komisja Europejska, 2003a). W dokumentach tych podkreślono przede wszystkim, że szybki rozwój Europejskiej Polityki Bezpieczeństwa i Obrony wymaga zasobów kosmicznych, co z kolei wiąże się z koniecznością zwrócenia większej uwagi polityków na kwestię rozwoju europejskiej polityki kosmicznej.

W Dokumencie Roboczym w sprawie wkladu potencjatu kosmicznego w EPBiO sprawozdawca komisji spraw zagranicznych Parlamentu Europejskiego zauważył, że „dla krajów UE sprawą zasadniczą jest posiadanie dostępu do danych" zdobywanych przez systemy satelitarne, by ,zapewnić decydentom w ramach EPBiO i WPZiB odpowiednie informacje”. Jednocześnie podkreślono, że budowa autonomicznych zdolności kosmicznych Unii Europejskiej nie może dublować starań podejmowanych przez państwa członkowskie UE, które zawierają umowy dwu- i wielostronne. Takie działania byłyby bowiem kosztowne i popierać należy umowy wielostronne jako „sposób zaoszczędzenia pieniędzy podatników" (Parlament Europejski, 2008a, s. 3). Konkluzje z Dokumentu Roboczego pojawiały się w rezolucji Parlamentu Europejskiego z lipca 2008 roku, w której wskazano, że zarówno system Galileo, jak i GMES są niezbędne „dla niezależnych operacji prowadzonych w ramach EPBiO, dla wspólnej polityki zagranicznej i bezpieczeństwa, bezpieczeństwa samej Europy oraz dla strategicznej autonomii Unii" (Parlament Europejski, 2008b).

Istotnym dokumentem jest także przyjęty w listopadzie 2004 roku dokument Rady European Space Policy: „ESDP and Space”, w którym Rada wskazała na konieczność implementacji europejskiej strategii bezpieczeństwa przy wykorzystaniu zdolności kosmicznych będących w zasobach państw członkowskich UE (Rada Unii Europejskiej, 2004). Szczegółowe ustalenia, określające dokładnie potrzeby wojskowe związane z zasobami kosmicznymi znalazły się w przyjętym w lutym 2006 roku przez Radę ds. Ogólnych i Stosunków Zewnętrznych dokumencie Generic Space Systems Needs for Military Operations (6091/06) (Kolovos, 2009, s. 9) uzupełnionym przez utajniony dokument Space System Requirements przyjęty również w lutym 2006 roku. 
Analiza wskazanych dokumentów pokazuje, że potrzeba zastosowania zasobów kosmicznych dla realizacji celów Wspólnej Polityki Bezpieczeństwa i Obrony podkreślana jest właściwie przez wszystkie zaangażowane podmioty. Oznacza to wolę do budowania kompleksowej i wielowymiarowej pozycji Unii Europejskiej przez zaangażowane podmioty. Jedynym wyjątkiem pozostaje Europejska Agencja Kosmiczna, której przedstawiciele wielokrotnie podkreślali wolę zaangażowania $\mathrm{w}$ działania mające wyłączenie charakter pokojowy. Fakt, że Komisja Europejska wnosi obecnie największy wkład do budżetu ESA może jednak wpłynąć na zmianę stanowiska, o czym w dalszej części pracy.

\section{Charakterystyka wykorzystania zasobów kosmicznych na potrzeby Wspólnej Polityki Bezpieczeństwa i Obrony}

Zgodnie z założeniami Dokumentu roboczego w sprawie wkładu potencjatu kosmicznego w EPBiO wskazać można na pięć sposobów wykorzystania systemów satelitarnych tj.: 1) obserwacja Ziemi i rozpoznanie, 2) telekomunikacja, 3) nawigacja, 4) lokalizacja i 5) synchronizacja. Obecnie na potrzeby WPBiO wykorzystywany jest jednak tylko częściowo pierwszy z systemów, co wynika przede wszystkim z braku zdolności technicznych Unii Europejskiej związanych między innymi z opóźnieniami w realizacji systemu Galileo. Nieudane wyniesienie na orbitę dwóch satelitów Galileo 22 sierpnia 2014 roku odsuwa start systemu na kolejne lata.

System obserwacji i rozpoznawania ziemi Copernicus, znaczy wcześniej pod nazwą GMES, miał zgodnie z początkowymi założeniami zapewnić monitorowanie zmian środowiskowych (Komisja Europejska, 2009), ale później koncepcja została rozszerzona, by włączyć też kwestie bezpieczeństwa i realizować cele z zakresu WPZiB oraz WPBiO (Rohner, Schrogl, Cheli, 2007). System Copernicus/GMES różni się od podejmowanych działań podobnego rodzaju przez państwa europejskie, gdyż za cel postawiono zbudowanie całościowego systemu, który nie tylko dostarczałby informacje z satelitów rozpoznawczych, ale również je klasyfikował i uzupełniał o dane pozyskane z innych źródeł. Dlatego też oprócz pierwotnego pomysłu monitorowania zmian klimatycznych i wczesnego ostrzegania o zagrożeniach środowiskowych, systemowi Copernicus przypisano również funkcje monitorowania granic, skupisk ludności oraz przemieszczania się ludności, a także wspierania zapobiegania konfliktom, zarządzania kryzysami, weryfikowania traktatów i umów, kontroli zbrojeń czy porozumień dotyczących środowiska. Tym samym zaproponowany system obejmuje zarówno wewnętrzny, jak i zewnętrzny aspekt aktywności Unii Europejskiej. Ponadto włączenie systemu Copernicus w system ochrony granic Unii Europejskiej EUROSUR przekłada się na wzrost bezpieczeństwa na terenie UE w związku z narastającą nielegalną imigracją.

Zasoby kosmiczne będące $\mathrm{w}$ posiadaniu państw europejskich podzielić można na cztery typy satelitów: satelity obserwacyjne, telekomunikacyjne, pozycjonujące i zapewniające wczesne ostrzeganie. Systemy składające się z dwóch ostatnich typów satelitów, stanowiące podstawę europejskich programów Galileo i Copernicus, są dopiero w fazie rozwojowej i ich przydatność nie została jeszcze zweryfikowana w prak- 
tyce (Giannopapa, 2012; Gleason, 2009; von der Dunk, 2006). Obecnie na potrzeby Wspólnej Polityki Bezpieczeństwa i Obrony wykorzystywane są dwa rodzaje danych dostarczanych przez Centrum Satelitarne Unii Europejskiej. Pierwszy rodzaj danych to zdjęcia satelitarne (IMINT) otrzymywane od państw europejskich na mocy specjalnych porozumień zawartych pomiędzy UE i państwami posiadającymi zasoby pozwalające na dostarczanie tego rodzaju danych. Obecnie EUSC wykorzystuje dane z satelitów wywiadowczych Helios (Belgia, Francja, Grecja i Hiszpania), SAR-Lupe (Niemcy), TerraSAR-X (Niemcy), COSMO-SkyMed (Włochy) oraz Pléiades (Francja). Systemy te wyposażone są zarówno w systemy optyczne, jak i radary o syntetycznej aperturze (SAR) pozwalające na prowadzenie obserwacji powierzchni ziemi w każdych warunkach atmosferycznych. Rozdzielczość zdjęć uzyskiwanych przez satelity europejskie waha się od $40 \mathrm{~cm}$ (Helios II) - $50 \mathrm{~cm}$ (Pléiades, SAR-Lupe) do $1 \mathrm{~m}$ (COSMO-SkyMed). Pierwszy satelita będący częścią programu kosmicznego Unii Europejskiej Sentinel-1 został wyniesiony na orbitę 3 kwietnia 2014 roku i wyposażony został radar o syntetycznej aperturze pozwalający na uzyskanie zdjęć o rozdzielczości 5 metrów. Kolejny satelita, Sentinel-2A, pierwszy z pary satelitów, zostanie wystrzelony w kwietniu 2015 roku i dostarczać będzie zdjęcia o rozdzielczości 10 metrów. Wyniesienie na orbitę satelitów Sentinel teoretycznie pozwoli UE na uzyskanie autonomiczności w zakresie wykorzystania zasobów kosmicznych na potrzeby Wspólnej Polityki Bezpieczeństwa i Obrony. Niemniej możliwości techniczne, jakie zapewnią satelity Sentinel są mniejsze w porównaniu z tym co posiadają w swych zasobach państwa europejskie, a zatem istniała będzie konieczność uzupełniania danych z dotychczasowych źródeł. Istotny jednak jest fakt uzyskania niezależnego dostępu do danych satelitarnych, co w przypadku autonomiczności Wspólnej Polityki Bezpieczeństwa i Obrony jest kluczowym elementem.

Drugi typ danych dostarczanych przez EUSC są dane wywiadowcze geoprzestrzenne (GEOINT), które łączą uzyskiwane obrazy z danymi innego typu, dając możliwość przewidywania wydarzeń zachodzących w obszarze konfliktu. Pozwala to na przykład na określenie możliwych sposobów rozwoju konfliktu, dróg ewakuacji uchodźców czy umiejscowienia baz. Dane tego typu są szczególnie przydatne w obszarach, gdzie istniejące mapy są niedokładne bądź przestarzałe. Połączenie zdjęć satelitarnych z danymi uzyskanymi przez obrazowanie SAR pozwala uwzględnić niwelację terenu, co stanowi istotną pomoc w planowaniu i wykonywaniu zadań w ramach Wspólnej Polityki Bezpieczeństwa i Obrony.

Satelity obserwacyjne i ich wykorzystanie w WPBiO to przede wszystkim obserwowanie środowiska naturalnego, monitorowanie potencjalnych kryzysów, jak również ich przewidywanie, planowanie operacji, a także bezpośredni nadzór nad podejmowanymi działaniami. Dane uzyskane z satelitów obserwacyjnych pozwalają także na wykonywanie zadań w ramach WPBiO po zakończeniu kryzysu, wraz z tym jak zdjęcia satelitarne pokazują $\mathrm{w}$ jaki sposób wykonywane są postanowienia porozumień pokojowych lub zawieszenia broni (Jentzsch, 2010). Wykorzystanie obserwacji satelitarnej przez UE ogranicza konieczność wprowadzania sił (obserwatorów) na teren konfliktu, co nie tylko ogranicza możliwe straty w ludziach, ale również przyczynia się do neutralnego podejścia do rozwiązywania konfliktów, promowanego przez Unię Europejską. Brak zaangażowania sił UE na obszarze konfliktu i fizycznej obecności wojsk 
lub obserwatorów cywilnych ogranicza możliwość posądzenia o sprzyjanie stronom konfliktu, bądź wspieranie określonych grup.

Należy również wspomnieć o prawno-międzynarodowym wymiarze wykorzystania obserwacji satelitarnej na potrzeby Wspólnej Polityki Bezpieczeństwa i Obrony. Systemy rozpoznania satelitarnego, zgodnie z rezolucją ONZ A/RES/41/65 przyjęta w 1986 roku dotycząca teledetekcji, są zgodne z prawem międzynarodowym i Układem o zasadach działalności państw w zakresie badania i użytkowania przestrzeni kosmicznej, który w art. I odnosi się do swobodnego wykorzystania przestrzeni kosmicznej (Układ o zasadach działalności państw w zakresie badania i użytkowania przestrzeni kosmicznej łącznie z Księżycem i innymi ciałami niebieskimi, sporządzony w Moskwie, Londynie, Waszyngtonie, 1967). Przyjęte przez ONZ zasady pozwalają nie tylko na prowadzenie obserwacji przy użyciu urządzeń optycznych, ale przede wszystkim teledetekcji, czyli wykorzystaniu danych uzyskanych przez odbiór fal odbitych, emitowanych lub ugiętych przez obiekty na powierzchni kuli ziemskiej. Zgodnie $\mathrm{z}$ zasadą I i IV wspomnianej rezolucji teledetekcja powinna być prowadzona $\mathrm{w}$ interesie wszystkich państw (Czapliński, Wyrozumska, 2004, s. 175). Tym samym jeśli przyjąć, iż działania tego typu są w interesie całej ludzkości, gdzie jednym z podstawowych celów jest utrzymanie pokoju międzynarodowego, obserwacja i teledetekcja satelitarna staje się narzędziem dla działań globalnych Unii Europejskiej. Jednocześnie, jak zauważa der Dunk, powstaje jednak skomplikowana sytuacja prawna (Von der Dunk, 2008, s. 440), gdyż w teledetekcję zaangażowane są poszczególne państwa członkowskie, ESA, Unia Europejska, jak również prywatni operatorzy świadczący obecnie usługi na potrzeby systemu Copernicus.

Niemniej, przyjęte przez Radę Programową ds. Obserwacji Ziemi (PB-EO) Europejskiej Agencji Kosmicznej regulacje dotyczące dostępu do danych systemu Copernicus pochodzących z satelitów Sentinel (ESA 2009) oraz rozporząadzenie delegowane Komisji NR 1159/2013 (Komisja Europejska, 2013) wprowadzają istotne ograniczenia w wykorzystaniu i zastosowaniu danych dostarczanych przez Copernicus. Przede wszystkim wprowadzone zostały obostrzenia dotyczące zagrożeń dla bezpieczeństwa i Komisja zarezerwowała sobie prawo do oceny wrażliwości udostępnianych danych, gdyby oznaczać mogło to „wykorzystanie informacji z usług GMES do działań taktycznych lub operacyjnych na szkodę interesów bezpieczeństwa Unii, jej państw członkowskich lub partnerów międzynarodowych" (art. 14).

Drugim z systemów, który będzie wykorzystywany na potrzeby Wspólnej Polityki Bezpieczeństwa i Obrony jest system Galileo. Jego zastosowanie może być szczególnie przydatne na przykład przy precyzyjnym naprowadzaniu pocisków, poprawieniu logistyki w teatrze działań operacyjnych, śledzenia zasobów i pozycji wroga, wzmacniania zdolności synchronizacji przemieszczania się różnych jednostek, zwiększania znajomości pola walki, polepszania skuteczności uderzeniowej, czy też redukcji możliwości przypadkowego ostrzału własnych lub sojuszniczych sił i zasobów. Kluczowe zastosowania Galileo obejmą również takie działania, jak kontrola graniczna, zarządzanie transportem i logistyka czy też obserwacja krytycznej infrastruktury energetycznej i komunikacyjnej. Pełna zdolność operacyjna systemu nawigacji planowana była na 2013 rok (pierwotnie na 2008 rok) i została przesunięta z powodów finansowych i technicznych (Gleason, 2009; Nardon, 2009). Część autorów podkreśla również czynniki 
geoekonomiczne, jako możliwą przyczynę opóźnień w realizacji europejskiego programu nawigacji satelitarnej (Grosse, 2014). Najprawdopodobniej wstępna zdolność, to jest 18 satelitów wraz z odpowiednią infrastrukturą naziemną, zostanie osiągnięta około roku 2014-2015. Pełna zdolność operacyjna systemu może zostać osiagnięta dopiero w latach 2019-2020, gdyż szacuje się, że około 1,9 miliarda euro potrzeba na stworzenie systemu złożonego z 30 satelitów oraz około 800 milionów każdego roku na bieżącą realizację projektu.

\section{Perspektywy wykorzystania zasobów kosmicznych dla realizacji celów Wspólnej Polityki Bezpieczeństwa i Obrony}

Wzmocnienie kosmicznej niezależności UE w wymiarze komercyjnym i strategicznym jest postrzegane bardziej przez pryzmat użyteczności publicznej, niż czysto rynkowego przedsięwzięcia, a poszczególne instrumenty polityki kosmicznej są traktowane jako ważne narzędzia wzmacniające skuteczność WPZiB i WPBiO. Ponadto, bez odpowiednich zasobów kosmicznych i jasno sformułowanej polityki kosmicznej, Unia Europejska nie zmieni politycznego, militarnego i komercyjnego monopolu amerykańskiego w obszarze działań kosmicznych. Analiza aktywności podmiotów zaangażowanych w europejską politykę kosmiczną pozwala postawić tezę, że głównym uczestnikiem staje się Komisja Europejska, jako najważniejsza instytucja zarówno nadająca kierunek i tempo zmian w tym obszarze, jak również posiadająca wyłączne prerogatywy od zarządzania zasobami kosmicznymi Unii Europejskiej w kontekście zapewniania i dostarczania bezpieczeństwa. Podmiot ten posiada, jak wspomniano powyżej, prawo do ograniczenia dostępu do zasobów Copernicus, jeśli zagraża to interesom i bezpieczeństwu państw członkowskich Unii Europejskiej lub jej partnerom. Pojawia się jednak problem nadzoru demokratycznego nad działaniami Komisji, bowiem Parlament Europejski poza kontrolą budżetu i udanym objęciem polityki kosmicznej zwykła procedurą ustawodawczą (Sigalas, 2012) nie ma możliwości nadzoru nad działaniami podejmowanymi przez Komisję. Decyzja o ograniczeniu dostępu do danych Copernicus podejmowana będzie przy udziale Komitetu Politycznego i Bezpieczeństwa, ale nadal w rękach Komisji pozostaje kontrola tego obszaru.

Drugie wyzwanie wiąże się z przyjętym stanowiskiem Komisji ujętym w komunikacie Komisji „Ustanowienie odpowiednich stosunków między UE a Europejską Agencją Kosmiczną" z listopada 2012 roku. Komisja sugeruje wprost, że obecna forma relacji pomiędzy UE i ESA utrudnia realizację zadań w kontekście zagadnień bezpieczeństwa i obrony, gdyż „,złonkami ESA są państwa niebędące członkami UE, co stanowi problem w wymiarze ogólnym" (Komisja Europejska, 2012, s. 4). Kwestie te zasygnalizowane zostały we wcześniejszym Komunikacie z 2011 roku, w którym Komisja wskazała, że wymiar polityki kosmicznej dotyczący bezpieczeństwa wymaga poważnych zmian, a ESA powinna ewoluować w kierunku organizacji o wymiarze międzyrządowym i unijnym, w której mogłyby współistnieć programy wojskowe i cywilne (Komisja Europejska, 2011). Przedstawione zostały trzy warianty, których wykonanie powinno mieć miejsce w latach 2020-2025. Pierwszy z wariantów zakłada poprawę współpracy przy zachowaniu status quo. W wariancie drugim ESA miałaby 
być włączona jako organizacja międzyrządowa w zakres kompetencji Unii Europejskiej, podobnie jak ma to miejsce w przypadku Europejskiej Agencji Obrony. Rozwiązanie trzecie zakłada przekształcenie ESA w agencję UE na wzór istniejących agencji regulacyjnych, co oznaczałoby de facto rozwiązanie ESA w obecnym kształcie. Działania zaproponowane przez Komisję wynikają z kilku przesłanek, ale przede wszystkim z faktu, że Komisja jest największym płatnikiem ESA i chciałaby sprawować kontrolę nad jej działaniami. Istotne jest, że Komisja nie proponuje likwidacji ESA, ale przyjęła politykę stopniowego ograniczania prerogatyw, by w przyszłości przejąć w całości struktury ESA. Proces ten zaplanowany jest na lata, tak by przedstawiciele państw ,przyzwyczaili” się do perspektywy dominacji UE w obszarze polityki kosmicznej, a istnienie ESA w obecnej formie uznane zostanie za bezpodstawne. Przyjęte konkluzje Rady z 26 maja 2014 roku sugerują jednak, że przekształcenie ESA w agencję UE wymagałoby konsensusu politycznego, jakiego osiagnięcie w przewidywalnej przyszłości może być trudne, a zatem obecnie realizowanym wariantem jest utrzymanie status quo lub stopniowe przekształcanie w organizację międzyrządową na wzór EDA (Rada Europejska, 2014).

Reasumując, chociaż obecny stan rozwoju programów kosmicznych Unii Europejskiej w kontekście możliwego ich wykorzystania dla realizacji celów Wspólnej Polityki Bezpieczeństwa i Obrony jest daleki od zamierzonych, należy podkreślić ich polityczną i strategiczną istotność. Nie bez znaczenia jest fakt, że zarówno Galileo jak i GMES/Copernicus są projektami niezwykle kosztownymi i złożonymi, co przekłada się na trudności z terminowym osiagnieciem zakładanych celów. Należy jednak traktować poszczególne instrumenty polityki kosmicznej jako ważne narzędzia wzmacniające skuteczność WPZiB i WPBiO. Ponadto, bez odpowiednich zasobów kosmicznych i jasno sformułowanej polityki kosmicznej, Unia Europejska nie zmieni politycznego, militarnego i komercyjnego monopolu amerykańskiego w obszarze działań kosmicznych. Ponadto nie będzie w stanie skutecznie zapewnić bezpieczeństwa nie tylko personelowi misji Unii Europejskiej, ale również bezpieczeństwa granic UE i państw bezpośrednio graniczących z Unią Europejską.

\section{Bibliografia}

Asbeck F. (2008), EU Satellite Center - A bird's eye view in support of ESDP operations, „ESDP Newsletter", nr 8, s. 22-23.

Brachet G., Deloffre B. (2006), Space for defence: A European vision, „Space Policy”, vol. 22, nr 2, s. 92-99.

Czapliński W., Wyrozumska A. (2004), Prawo międzynarodowe publiczne, Wydawnictwo C. H. Beck, Warszawa.

European Space Agency (2009), Joint Principles for a GMES Sentinel Data Policy, ESA/PB-EO(2009)98, rev. 1, 23.10.2009.

Giannopapa C. (2012), Securing Galileo's and GMES's place in European policy, „Space Policy”, vol. 28 , nr 4, s. 270-282.

Gleason M. (2006), European Union Space Initiatives: The Political Will for Increasing European Space Power, „Astropolitics: The International Journal of Space Politics and Policy”, vol. 4, nr 1, s. 7-41. 
Gleason M. (2009), Galileo: Power, Pride, and Profit. The Relative Influence of Realist, Ideational, and Liberal Factors on the Galileo Satellite Program, DTIC Document 2009, http:/oai.dtic.mil/oai/oai?verb=getRecord\&metadataPrefix=html\&identifier=ADA495023, 1.08.2014.

Grosse T. G. (2014), Geoeconomic Relations Between the EU and China: The Lessons From the EU Weapon Embargo and From Galileo, „Geopolitics”, vol. 19, nr 1, s. 40-65.

Jentzsch J. (2010), Use of Satellite Data for Treaty Monitoring, w: Current Legal Issues for Satellite Earth Observation, red. M. Sánchez Aranzamendi, R. Sandau, K.-U. Schrogl, ESPI, Wien, s. $27-30$.

Kolovos A. (2009), The European Space Policy-Its Impact and Challenges for the European Security and Defence Policy, „European Space Policy Perspectives”, vol. 27, s. 1-17.

Komisja Europejska (2003a), White Paper on Space: a new European frontier for an expanding Union - An action plan for implementing the European Space Policy, COM (2003) 673, 11.01.2003.

Komisja Europejska (2003b), European Space Policy. Green Paper, COM (2003) 17 final, 21.01.2003.

Komisja Europejska (2009), Globalny Monitoring Środowiska i Bezpieczeństwa (GMES): Wyzwania i kolejne działania dotyczace komponentu kosmicznego, KOM (2009) 589 końcowy, 28.10.2009.

Komisja Europejska (2011), Ku strategii Unii Europejskiej w zakresie przestrzeni kosmicznej w stużbie obywateli, KOM (2011) 152 wersja ostateczna 4.04.2011.

Komisja Europejska (2013), ROZPORZĄDZENIE DELEGOWANE KOMISJI (UE) NR 1159/2013 $z$ dnia 12 lipca 2013 r. uzupetniajace rozporzadzenie Parlamentu Europejskiego i Rady (UE) nr 911/2010 w sprawie europejskiego programu monitorowania Ziemi (GMES) poprzez ustanowienie warunków rejestracji i licencjonowania dla użytkowników GMES i określenie kryteriów ograniczajacych dostęp do danych do celów GMES i informacji z ustug GMES, Dz. Urz. UE L 309, 19.11.2013, http://eur-lex.europa.eu/legal-content/PL/TXT/HTML/?uri=CELEX:32013R1159\&from=EN.

Komisja Europejska (2012), Ustanowienie odpowiednich stosunków między UE a Europejska Agencja Kosmiczna, KOM (2012) 671 final, 14.11.2012.

Maogoto J. N., Freeland S. (2008), From Star Wars to Space Wars'-The Next Strategic Frontier: Paradigms to Anchor Space Security, „Air and Space Law”, vol. 33, nr 1, s. 10-37.

Mutschler M. M., Venet C. (2012), The European Union as an emerging actor in space security?, „Space Policy”, vol. 28, nr 2, s. 118-124.

Nardon L. (2009), Galileo and the Issue of Public Funding, w: Yearbook on Space Policy 2007/2008: From Policies to Programmes, red. K.-U. Schrogl, C. Mathieu, N. Peter, Springer Science \& Business Media, Wien, s. 125-137.

Parlament Europejski (2008a), Dokument Roboczy w sprawie wktadu potencjalu kosmicznego w EPBiO, PE 400.583v01-00, 30.01.2008.

Parlament Europejski (2008b), Rezolucja legislacyjna Parlamentu Europejskiego z dnia 10 lipca 2008 r. w sprawie przestrzeni kosmicznej i bezpieczeństwa, P6_TA(2008)0365, 10.07.2008.

Parlament Europejski (2006), Europe's Space Policies and their relevance to ESDP, PE 381.369, 19.06.2006.

Rada Europejska (2014), Ku wspólnej wizji UE i ESA wspierania konkurencyjności dzięki przestrzeni kosmicznej, 9851/14, 26.05.2014.

Rada Unii Europejskiej (2004), ESDP and Space, 11616/3/04, 16.11.2004.

Rohner N., Schrogl K.-U., Cheli S. (2007), Making GMES better known: Challenges and opportunities, „Space Policy”, vol. 23, nr 4, s. 195-198. 
Sigalas E. (2012), The role of the European parliament in the development of a European union space policy, „Space Policy”, vol. 28, nr 2, s. 110-117.

Słomczyńska I. (2007a), Europejska Polityka Bezpieczeństwa i Obrony. Uwarunkowania - struktury - funkcjonowanie, Wydawnictwo UMCS, Lublin.

Słomczyńska I. (2007b), Europejska Polityka Bezpieczeństwa i Obrony jako problem badawczy w nurcie badań nad integracjq europejska, „Przegląd Europejski”, vol. 15, nr 2, s. 63-74.

Uktad o zasadach działalności państw w zakresie badania i użytkowania przestrzeni kosmicznej tacznie z Księżycem i innymi ciałami niebieskimi, sporzadzony w Moskwie, Londynie, Waszyngtonie (1968), Dz. U. 1968, Nr 14, poz. 82, 27.01.1967.

Von der Dunk F. G. (2008), European satellite Earth observation: law, regulations, policies, projects, and programmes, „Creighton Law Review”, vol. 42, nr 3, s. 397-446.

Von der Dunk F. G. (2006), Towards Monitoring Galileo: The European GNSS Supervisory Authority in Statu Nascendi/Zur Kunftigen Uberwachungsagentur des Galileo Systems „Zeitschrift fur Luft- und Weltraumrecht", vol. 55, nr 1, s. 100-117.

Western European Union (2001), A joint European space strategy: security and defence aspects". Assembly of Western European Union. Forty-seventh session. Document A/1738, 20.06.2001, WEU-96.011, Historical Archives of the EU.

Western European Union (1998), Proceedings Vol. I, forty-fourth session, first part, May 1998 - Assembly document 1612. WEU Council of Ministers 11-12 may 1998, Rhodes Declaration, 15.05.1998, WEU-90.015, Historical Archives of the EU.

Western European Union (1965), Recommendation 130 on the state of European space activites. The political choice, 17.11.1965, ELCO/Sec (66) 76, ELDO-1952, Historical Archives of the EU.

Western European Union (2008), Recommendation 830, Multinational space-based imaging system (MUSIS): European space cooperation for security and defence, 2.12.2008, DOCUMENT A/2025, WEU-111.015, Historical Archives of the EU.

Western European Union (1984), The military use of space. Proceedings Vol. I, Thirtieth session, first part, June 1984 - Assembly document 976, 15.05.1984, WEU-58.011, Historical Archives of the EU.

Western European Union (2004), The space dimension of the ESDP. Proceedings Vol. III, fiftieth session, first part, November-December 2004 - Assembly document A/1881, 30.11.2004, WEU-91.019, Historical Archives of the EU.

\section{Streszczenie}

Europejska Polityka Kosmiczna wprowadzona w życie Traktatem z Lizbony związana jest z całościowym podejściem Unii Europejskiej do działań zewnętrznych. Wiąże się z tym wykorzystanie zasobów kosmicznych na potrzeby Wspólnej Polityki Bezpieczeństwa i Obrony. W pracy scharakteryzowano genezę, przesłanki, podstawy prawne dla wykorzystania zasobów kosmicznych UE w realizacji zadań WPBiO. W kolejnych częściach analizie poddano realizowane programy dotyczące Europejskiej Polityki Kosmicznej oraz ich wykorzystanie na potrzeby WPBiO. Realizowane przez Unię Europejską działania, tj. programy Copernicus oraz Galileo, pomimo, że są obecnie w początkowej fazie realizacji stanowią istotny element całościowej wizji uczestnictwa Unii Europejskiej w stosunkach międzynarodowych. Zmiany zachodzące w tym wymiarze związane są nie tylko ze zdobyciem nowych instrumentów kształtowania środowiska międzynarodowego, w postaci satelitów nawigacyjnych i rozpoznawczych, ale również postulowanej przez Komisję Europejską konsolidacji działań w przestrzeni 
kosmicznej podejmowanych przez państwa europejskie. Wiąże się to prowadzonymi pracami nad zmianą charakteru współpracy UE z Europejską Agencją Kosmiczną oraz stopniowym nadawaniem wymiaru militarnego aktywności UE w przestrzeni kosmicznej.

Słowa kluczowe: Unia Europejska, Wspólna Polityka Bezpieczeństwa i Obrony, polityka kosmiczna, GMES/Copernicus, Galileo

\title{
The use of the space assets of the European Union for the purposes of the Common Security and Defence Policy
}

\begin{abstract}
Summary
The European Space Policy as implemented by the Lisbon Treaty is associated with the EU's comprehensive approach to external action. This involves the use of space assets for the purposes of the Common Security and Defence Policy. The paper describes the origins, rationale and legal basis for the use of space assets in the tasks of the EU CSDP. The paper analyses the programmes implemented under the European Space Policy and their application in the CSDP. The space programmes implemented by the European Union, i.e. Copernicus and Galileo, although still in the initial stages of implementation, are an important part of the overall vision of the European Union's participation in international relations. Changes in this dimension are directly linked not only to acquiring new instruments to shape the international environment, through a European satellite navigation system and satellite reconnaissance, but also the consolidation of space activities undertaken by European countries as postulated by the European Commission. This is due to the ongoing work on the change of the EU's cooperation with the European Space Agency and the gradually expanding military dimension of EU activities in space.
\end{abstract}

Key words: European Union, Common Security and Defence Policy, space policy, GMES/Copernicus, Galileo 
